\title{
Bibliometric Analysis on Reverse Logistics in the Scopus Database: A Guide for Future Studies
}

\author{
Yang Kaihan, Thoo Ai Chin
}

To Link this Article: http://dx.doi.org/10.6007/IJARBSS/v11-i8/10694

DOI:10.6007/IJARBSS/v11-i8/10694

Received: 17 June 2021, Revised: 22 July 2021, Accepted: 12 August 2021

Published Online: 25 August 2021

In-Text Citation: (Kaihan \& Chin, 2021)

To Cite this Article: Kaihan, Y., \& Chin, T. A. (2021). Bibliometric Analysis on Reverse Logistics in the Scopus Database: A Guide for Future Studies. International Journal of Academic Research in Business and Social Sciences, 11(8), 1715-1727.

\section{Copyright: @ 2021 The Author(s)}

Published by Human Resource Management Academic Research Society (www.hrmars.com)

This article is published under the Creative Commons Attribution (CC BY 4.0) license. Anyone may reproduce, distribute, translate and create derivative works of this article (for both commercial and non-commercial purposes), subject to full attribution to the original publication and authors. The full terms of this license may be seen at: http://creativecommons.org/licences/by/4.0/legalcode

Vol. 11, No. 8, 2021, Pg. 1715 - 1727

Full Terms \& Conditions of access and use can be found at http://hrmars.com/index.php/pages/detail/publication-ethics 


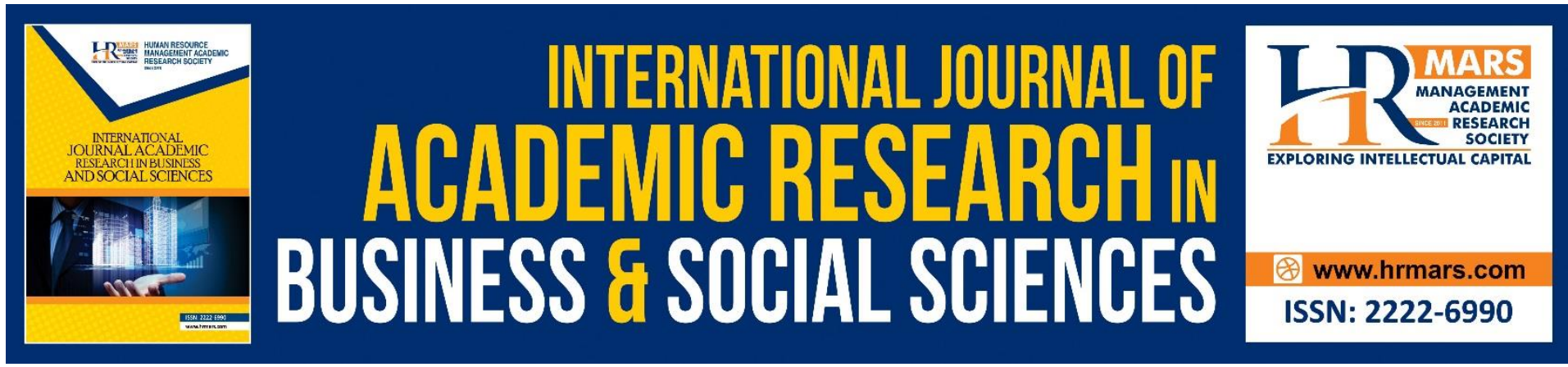

\title{
Bibliometric Analysis on Reverse Logistics in the Scopus Database: A Guide for Future Studies
}

\author{
Yang Kaihan, Thoo Ai Chin \\ Azman Hashim International Business School, Universiti Teknologi Malaysia, 81310 Skudai, \\ Malaysia. \\ Email: yangkaihan@graduate.utm.my
}

\begin{abstract}
The reverse logistics ( $R L$ ) concept has become increasingly popular due to the rising socioenvironmental crisis, encompassing climate changes, pollutions and numerous health issues caused by pollutions. Therefore, a bibliometric analysis was conducted on RL to guide future research. This study utilised the VOSviewer software to conduct a bibliometric analysis on RL from 1995 to 2020. Precisely, 1146 papers were retrieved and analysed to identify the most prolific and prominent authors and journals, co-authorship, and co-occurrence. The coauthorship and co-occurrence analysis findings discovered that the United States of America (USA) leads RL-related article publications as the authors and institutions' cooperation rate is high. 'Reverse logistics', 'remanufacture', and 'waste management' were the most critical keywords in the literature. The bibliometric analysis was undertaken to determine the trends in the RL field. The present research determined that the publication trend continuously increases and is forecasted to increase in the future constantly. The directions for RL and future studies were determined and demonstrated through the analysis.
\end{abstract}

Keywords: Reverse Logistics, Waste Management, Bibliometric Analysis, Co-Citation Analysis, Co-Occurrence Analysis

\section{Introduction}

The State of the Global Climate 2020 Report released in April 2020 by the World Meteorological Organisation (WMO) highlighted that 2020 was one of the hottest years recorded as the average temperature worldwide was $1.2{ }^{\circ} \mathrm{C}$ exceeding the pre-industrial baseline. Additionally, the annual mean global temperature is forecasted to be at the minimum $1^{\circ} \mathrm{C}$ hotter within the range of $0.9^{\circ} \mathrm{C}$ to $1.8^{\circ} \mathrm{C}$ higher compared to pre-industrial levels in the upcoming five years. The change in the temperature is a consequence of the increased global carbon emissions levels. Hence, the RL concept is considered advantageous due to lower carbon footprint levels (Nageswara et al., 2019). The RL can restore the flow from the consumption point to the origin point to regain value or execute appropriate processing (Ho et al., 2012; Bai and Sarkis, 2013).

$\mathrm{RL}$ is deemed a significant part of supply chain management (Wang et al., 2016). Lambert and Stock (1982) were among the first to describe RL as "going the wrong way on a one-way road because most products are transported in one-way" (p. 19). Subsequently, researchers 
revised the definition of $\mathrm{RL}$ to encompass additional precise functions and processes (e.g., Murphy, 1986; Murphy and Poist, 1989; Stocks, 1992; Kopicki et al., 1993; Carter and Ellram, 1998; Stocks, 1998). As a new supply chain management trend, RL aims to gain more competitive advantages in the fields of value, profitability, and sustainability and provide additional advantages for all industries. Besides, RL can be applied to industry practice under logistics management.

According to Mishra and Napier (2014), RL refers to the reverse flow of information and materials and the reuse, renewal and repossession of valuable parts and components by transforming them into new products and putting them back on the market. In addition, RL primarily focuses on the materials backflow from customers to suppliers by aiming to maximise the returned items' value or reduce the total cost. Similarly, the sequencing, remanufacturing, recycling and disposal of these products can be reutilised (Sharma et al., 2011). In this study, RL mainly implies the return of products from the consumption point to the source of origin.

Well-managed RL projects can achieve sustainability and create a competitive advantage by increasing profits, reducing costs (Banihashemi et al., 2019). RL creates tangible and intangible advantages by obtaining value from waste products and prolonging their service life rather than purchasing additional raw materials and misusing human resources and time. Furthermore, RL can also maintain customers' fondness for products by focusing on repairing or replacing defective products and showing a positive role in improving customer satisfaction with the products. In addition, RL can improve future products and design new products by integrating customer feedback information and determining the return factors (Aitken and Harrison, 2013).

Most studies emphasised the specific aspects of RL, such as modelling (Rogers et al., 2012), planning (Ramos et al., 2014), driving (Sharma et al., 2011), performance measurement, and the general overview of RL (Alkahtani et al., 2021). The development trend of $\mathrm{RL}$ must be necessarily analysed to comprehend $\mathrm{RL}$ research status. Thus, bibliometric analysis is one of the tools to achieve this purpose (Li et al., 2017). Analysing the definition of $\mathrm{RL}$ in the other areas of the literature with similar objectives and evaluating a considerable quantity of publications on these topics is beneficial. In addition, the subsequent bibliometric analysis assisted in revealing the structure of intelligence of RL. Therefore, this study discusses the bibliometric analysis findings, summarises the trend, and provides future RL research directions.

\section{Research Method}

\section{Analysis Tools and Methods}

Bibliometric analysis is a quantitative method that identifies and analyses data related to the keywords used and searched in the literature, their relationships, the number of articles published within a specific time frame and their citations (Evren and Kozak, 2014; Munoz-Leiva et al., 2015). In addition, a similar approach applies to other fields such as management information system (Culnan 1987), operations management (Pilkington and Liston-Heyes 1999), international management (Aedo and Casillas 2005), strategy, or less commonly religious topics in management (Gundolf and Filser 2013). Thus, management researchers can broaden their knowledge related to the theoretical structure of logistics and supply chain management (Charvet et al., 2008; Giannakis 2012; Georgi et al., 2013). 


\section{Data Gathering}

The data acquisition for the study was retrieved from the Scopus database. Scopus is the most extensive abstracts and citations database, with 1.4 billion citations and 16 million author data (Falagas et al., 2008; Franceschini et al., 2016; Scopus, 2020). Data mining for the study was carried out in 2020. The central research topic was a research article that contains "RL" and "reverse supply chain" in titles, abstracts or author keywords. Figure 1 exhibits complete details of the query strings utilised.

\section{Analysis and Results}

Figure 1. Search string with article inclusion and exclusion criteria

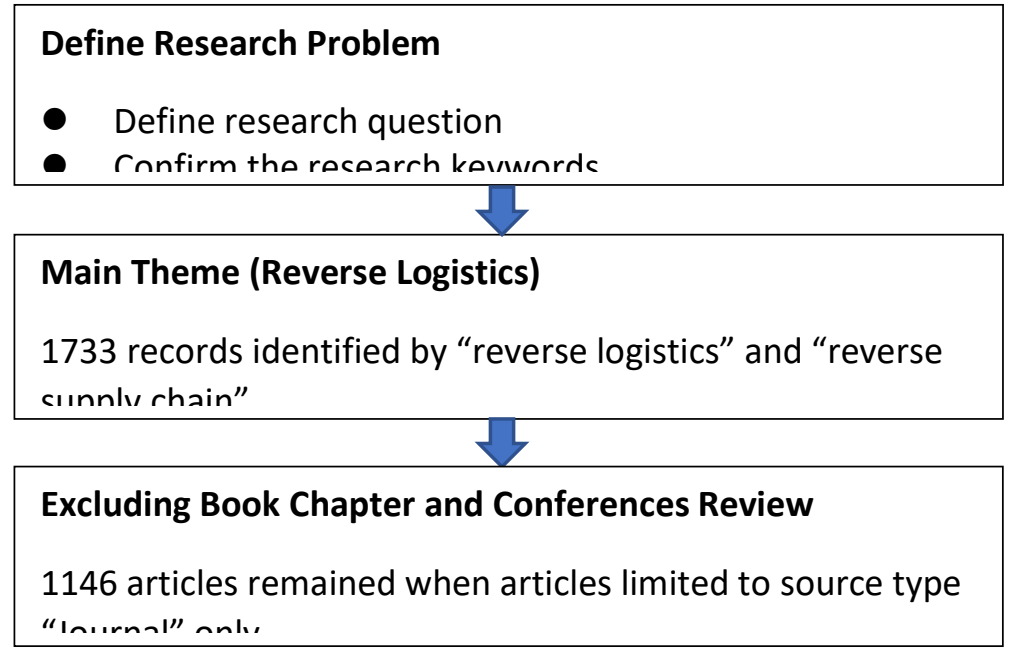

The analysis of documents and the results are presented in the following sections.

\section{Publication per Year}

Influenced by various factors, the RL concept has attracted increasing attention, including competition among organisations, social marketing, environmental interference and economic elements (Alkahtani et al., 2021). The number of annual publications from 1995 to 2020 in the RL field can be observed in Figure 2. RL has not been regarded as profitable by manufacturers (Blackburn et al., 2004; Jayaraman and Luo, 2007). Nevertheless, in the early 1990s, several researchers realised that manufacturers could provide economic and competitive opportunities while improving the environment if they attach equal importance to RL as traditional logistics (Stock, 1998; Dowlatshahi, 2005; Ravi and Shankar, 2005; Pourmohammadi et al., 2008). Resultantly, RL-related research has enormously increased since 1995. In addition, RL can promote sustainability and its strategic functions in numerous economic sectors (Ho et al., 2012; Lopes et al., 2014). Thus, organisations must take necessary RL measures (Ravi and Shankar, 2012; Agrawal et al., 2016). 


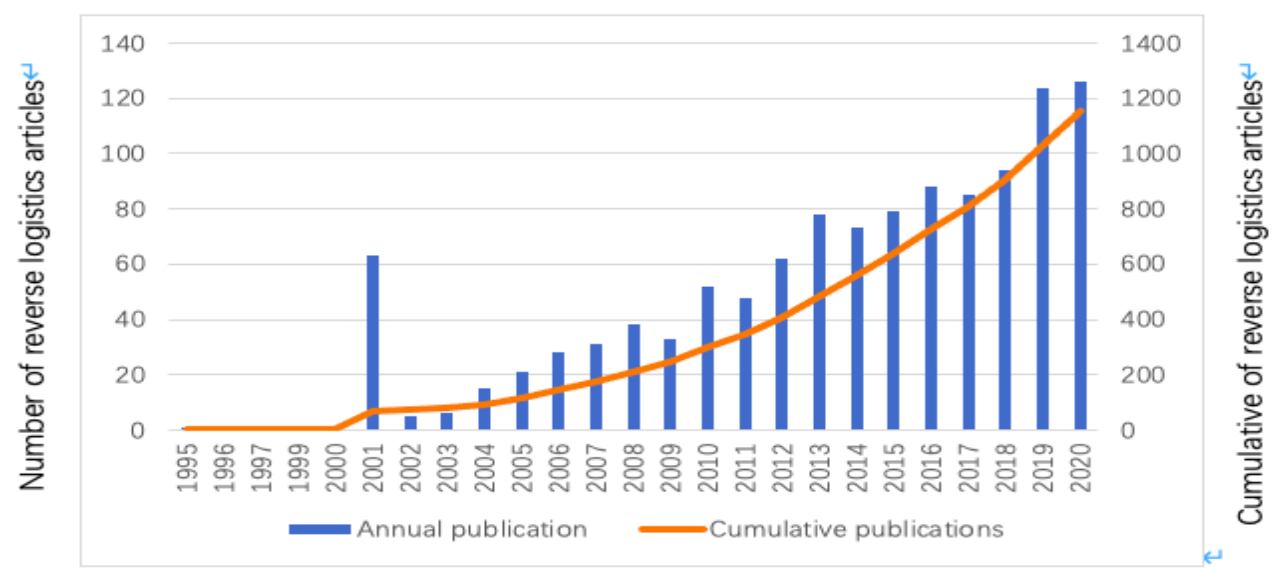

Figure 2. Number of annual publications in $\mathrm{RL}$ research

\section{Most Productive Journals}

Sharma (2011) pointed out that RL can bring economic benefits as $R L$ enable enterprises to regain the original lost value. Effective RL management can bring tremendous benefits to organisations, including improved performance, increased profits and customer satisfaction (Campos et al., 2017). As a result, RL has gained widespread attention in the business field (Tibben-Lembke and Rogers, 2002). In recent decades, considerable progress in understanding RL is evident, as observed in the rapidly increasing quantity of published research in recent years. The documentation shall be an effective method in determining the conceptual content of the study field and guiding future research (Raghuram et al., 2010), but determining the most closely related and significant articles is the key to the bibliography.

The prominent RL-related publishing journals are exhibited in Table $1 . \mathrm{RL}$ articles are concentrated in a restricted quantity of journals. $50 \%$ of RL-related studies are published in the top ten journals enlisted. The Journal of Cleaner Production tops the rank, whereas the International Journal of Production Economics has the most citations. Besides, CiteScore for both journals were the highest in 2010. The CiteScore can influence several authors' decisions in choosing journals that suit their original and noteworthy works. The leading ten journals encompass diverse topics that can be classified into five categories: (1) production and operations management, (2) operations research, (3) transport, logistics and supply chain management, (4) general management and strategy, and (5) environmental management. Numerous RL studies are published in production management, implying that RL might comprise theories beyond the limited scope of moving products backwards in space and time. Remarkably, from the top ten RL-related journals, only two specific to environmental management portray the lack of RL legitimacy in the environmentally concentrated research field. Furthermore, Bensalem (2019) highlighted the lack of theory development, particularly in the RL field and the absence of a specific journal on RL. 
Table 1. The top ten most productive journals on $\mathrm{RL}$ research with their most cited articles

\begin{tabular}{|c|c|c|c|c|c|c|}
\hline Journal & $\begin{array}{l}\text { TP } \\
(\%)\end{array}$ & TC & $\begin{array}{l}\text { Cite } \\
\text { Score } \\
2019 \\
\end{array}$ & The Most Cited Article (Reference) & $\begin{array}{l}\text { Time } \\
\text { Cited }\end{array}$ & Publisher \\
\hline $\begin{array}{l}\text { Journal of Cleaner } \\
\text { Production }\end{array}$ & 74 & 3017 & 8.4 & $\begin{array}{l}\text { A review of reverse logistics and } \\
\text { closed-loop supply chains: A Journal } \\
\text { of Cleaner Production focus }\end{array}$ & 223 & Elsevier \\
\hline $\begin{array}{l}\text { International Journal of } \\
\text { Production Economics }\end{array}$ & 55 & 4142 & 7.8 & $\begin{array}{l}\text { Design of sustainable supply } \\
\text { chains under the emission trading } \\
\text { scheme }\end{array}$ & 508 & Elsevier \\
\hline $\begin{array}{l}\text { International Journal of } \\
\text { Production Research }\end{array}$ & 54 & 2092 & 5.6 & $\begin{array}{l}\text { Environmental principles applicable } \\
\text { to green supplier evaluation by } \\
\text { using multi-objective decision } \\
\text { analysis }\end{array}$ & 257 & $\begin{array}{l}\text { Taylor \& } \\
\text { Francis }\end{array}$ \\
\hline Sustainability Switzerland & 24 & 163 & 2.6 & $\begin{array}{l}\text { Sustainable retailing in the fashion } \\
\text { industry: A systematic literature } \\
\text { review }\end{array}$ & 35 & $\begin{array}{l}\text { Taylor \& } \\
\text { Francis }\end{array}$ \\
\hline $\begin{array}{l}\text { Computers and Industrial } \\
\text { Engineering }\end{array}$ & 23 & 1226 & 4.1 & $\begin{array}{l}\text { A stochastic model for forward-RL } \\
\text { network design under risk }\end{array}$ & 252 & Elsevier \\
\hline $\begin{array}{l}\text { International Journal of } \\
\text { Physical Distribution and } \\
\text { Logistics Management }\end{array}$ & 22 & 1344 & 4.7 & $\begin{array}{l}\text { A model to define and assess the } \\
\text { agility of supply chains: Building on } \\
\text { humanitarian experience }\end{array}$ & 148 & Emerald \\
\hline $\begin{array}{l}\text { International Journal of } \\
\text { Logistics Systems and } \\
\text { Management }\end{array}$ & 21 & 251 & 1.4 & $\begin{array}{l}\text { Multi-objective decision modelling } \\
\text { using interpretive structural } \\
\text { modelling for green supply chains }\end{array}$ & 58 & Springer \\
\hline $\begin{array}{l}\text { International Journal of } \\
\text { Advanced Manufacturing } \\
\text { Technology }\end{array}$ & 20 & 832 & 2.6 & $\begin{array}{l}\text { The economics of cell phone reuse } \\
\text { and recycling }\end{array}$ & 179 & Springer \\
\hline $\begin{array}{l}\text { International Journal of } \\
\text { Logistics Management }\end{array}$ & 19 & 587 & 3.3 & The returns management process & 156 & Emerald \\
\hline $\begin{array}{l}\text { International Journal of } \\
\text { Supply } \\
\text { Management }\end{array}$ & 19 & 90 & 6.8 & $\begin{array}{l}\text { Sustainability in the food retail } \\
\text { industry through reverse logistics }\end{array}$ & 15 & $\begin{array}{l}\text { IGI } \\
\text { Global }\end{array}$ \\
\hline
\end{tabular}

*Note $=$ TP: Total Publication/ TC: Total Citation

\section{Most Influential Authors}

The substantial increase in RL research from 1995 indicates the significance of the RL (Agrawal et al., 2016). Table 2 provides the ten most prolific authors in the RL research area that helps in analysing the research focus. Govindan has published 20 papers related to RL as the most contributing author. According to the survey on Govindan publications, his study focuses on green, sustainable and environmental issues. Similarly, Sarkis, Vikas, Zhang, and Tavakkoli-Moghaddam focused on green and sustainability development. Furthermore, Govindan (2015) asserted that researchers favour suitable environmental, social, and greenbased objectives in their analyses that could be a crucial future avenue for all entities in the $\mathrm{RL}$ network. Thus, sustainability performance is a research focus among the ten most prolific authors of the RL research area. 
Rameezdeen and Chileshe, with the same research area of waste management, coauthored a paper entitled "Construction and demolition waste management in China through the 3R principle". Conversely, Sarkis is the only top ten contributing author in RL and GSCM (Green supply chain management) areas. He linked both study fields in his models and defined $\mathrm{RL}$ as the main component of GSCM. Most RL studies are undertaken in developed countries by analysing the current affiliation. Thus, RL studies on developing countries should pay attention in the future by analysing Table 2 .

Table 2. List of the ten most prolific authors in RL research area

\begin{tabular}{|c|c|c|c|c|c|c|c|c|}
\hline No & Author & $\begin{array}{l}\text { Scopus } \\
\text { Author ID }\end{array}$ & $\begin{array}{l}\text { Year of 1st } \\
\text { Publication }\end{array}$ & TP & $\begin{array}{l}\text { h- } \\
\text { index }\end{array}$ & TC & $\begin{array}{l}\text { Current } \\
\text { Affiliation }\end{array}$ & Country \\
\hline 1 & $\begin{array}{l}\text { Govindan, } \\
\text { Kannan }\end{array}$ & 54986334000 & 2011 & 20 & 81 & 3080 & $\begin{array}{l}\text { Syddansk } \\
\text { Universitet, } \\
\text { Odense, } \\
\text { Denmark }\end{array}$ & Denmark \\
\hline 2 & Diabat, Ali H. & 26646404900 & 2012 & 13 & 39 & 637 & $\begin{array}{l}\text { NYU Abu } \\
\text { Dhabi, Abu } \\
\text { Dhabi, United } \\
\text { Arab Emirates }\end{array}$ & $\begin{array}{l}\text { United } \\
\text { Arab } \\
\text { Emirates }\end{array}$ \\
\hline 3 & $\begin{array}{l}\text { Chileshe, } \\
\text { Nicholas }\end{array}$ & 12808688300 & 2015 & 11 & 22 & 156 & $\begin{array}{l}\text { University of } \\
\text { South } \\
\text { Australia, } \\
\text { Adelaide, } \\
\text { Australia }\end{array}$ & Australia \\
\hline 4 & $\begin{array}{l}\text { Rameezdeen, } \\
\text { Raufdeen }\end{array}$ & 6504205982 & 2015 & 11 & 22 & 156 & $\begin{array}{l}\text { University of } \\
\text { South } \\
\text { Australia, } \\
\text { Adelaide, } \\
\text { Australia }\end{array}$ & Australia \\
\hline 5 & $\begin{array}{l}\text { Amin, Saman } \\
\text { Hassanzadeh }\end{array}$ & 25649063200 & 2010 & 10 & 17 & 793 & $\begin{array}{l}\text { Ryerson } \\
\text { University, } \\
\text { Toronto, } \\
\text { Canada }\end{array}$ & Canada \\
\hline 6 & Sarkis, Joseph & 57194726123 & 2001 & 10 & 85 & 1087 & $\begin{array}{l}\text { Worcester } \\
\text { Polytechnic } \\
\text { Institute, } \\
\text { Worcester, } \\
\text { USA }\end{array}$ & USA \\
\hline 7 & $\begin{array}{l}\text { Zhang, } \\
\text { Guoqing }\end{array}$ & 56961166100 & 2010 & 9 & 25 & 1016 & $\begin{array}{l}\text { University of } \\
\text { Windsor, } \\
\text { Windsor, } \\
\text { Canada }\end{array}$ & Canada \\
\hline 8 & $\begin{array}{l}\text { Kumar, } \\
\text { Sameer } \\
\text { Vasanth }\end{array}$ & 55616292300 & 2006 & 8 & 34 & 600 & $\begin{array}{l}\text { University of } \\
\text { St. Thomas, } \\
\text { Minnesota, } \\
\text { Saint Paul, USA }\end{array}$ & USA \\
\hline
\end{tabular}


INTERNATIONAL JOURNAL OF ACADEMIC RESEARCH IN BUSINESS AND SOCIAL SCIENCES

Vol. 11, No. 8, 2021, E-ISSN: 2222-6990 @ 2021 HRMARS

$9 \quad$ Kumar, Vikas $36835614000 \quad 2012$

10 Tavakkoli-

572075337142012

Moghaddam,

$8 \quad 27$

573

University of United

the West of Kingdom

England,

Bristol, United

Kingdom

Reza

$8 \quad 52 \quad 573$

University of Iran

Tehran,

Tehran, Iran

\section{Co-authorship Country Analysis}

Table 3 exhibits that most RL studies were undertaken in developed countries. In addition, the country has more cooperation and productive academic institutions in this field. Of the 15 countries, only India (76.3\%), Iran (72.8\%), and Brazil (68.3\%) have more than two-thirds of single-country publications (SCPs), indicating solid internal cooperation between these countries. The benefits of international cooperation are not restricted to expanding networks, sharing expertise and exchanging knowledge, but also an efficient strategy for improving rankings.

Figure 3 exhibits the distribution of countries or regions. Based on the VosViewer, the closer the two countries are, the stronger the correlation and connection are, and the thicker between them. The USA, the United Kingdom and China have the most significant number of countries in each region. According to the co-authors, the USA was the most subordinate country, with 154 collaborations with 35 countries or regions. Numerous potential factors contributing to the impetus for international cooperation can be attributed to the research partners' diversity, the high percentage of foreign graduate or visiting scholars, and solid research funding. A flexible and stable relationship is also significant to warrant the sustainability of international cooperation.

Table 3. The top 15 most productive countries and academic institutions in RL publications

\begin{tabular}{|c|c|c|c|c|c|}
\hline Rank & Country & TPc & SCP (\%) & The Most Productive Academic Institutions & TPi \\
\hline 1 & USA & 206 & 53.4 & University of St. Thomas, Minnesota & 7 \\
\hline 2 & India & 152 & 76.3 & Delhi Technological University & 10 \\
\hline 3 & China & 135 & 54.8 & Harbin University of Commerce & 7 \\
\hline 4 & Iran & 103 & 72.8 & University of Tehran & 20 \\
\hline 5 & United Kingdom & 95 & 31.6 & Cranfield School of Management & 4 \\
\hline 6 & Brazil & 60 & 68.3 & Universidade Federal de Santa Catarina & 5 \\
\hline 7 & Canada & 59 & 42.4 & Ryerson University & 8 \\
\hline 8 & Malaysia & 47 & 61.7 & Universiti Utara Malaysia & 5 \\
\hline 9 & France & 45 & 28.9 & Université Fédérale Toulouse Midi-Pyrénées & 4 \\
\hline 10 & Taiwan (China) & 44 & 70.5 & Chung Yuan Christian University & 5 \\
\hline 11 & Germany & 41 & 56.1 & Universität Augsburg & 4 \\
\hline 12 & Australia & 37 & 59.5 & University of South Australia & 13 \\
\hline 13 & Denmark & 37 & 13.5 & Syddansk Universitet & 3 \\
\hline 14 & Italy & 37 & 54.1 & Universita del Salento & 3 \\
\hline 15 & Turkey & 29 & 62.1 & Istanbul Teknik Üniversitesi & 5 \\
\hline
\end{tabular}

*Note $=$ Abbreviation: TPc - Total Publications of a Given Country/ TPi - Total Publications of a

Given Academic Institution/ SCP - Single-Country Publications 


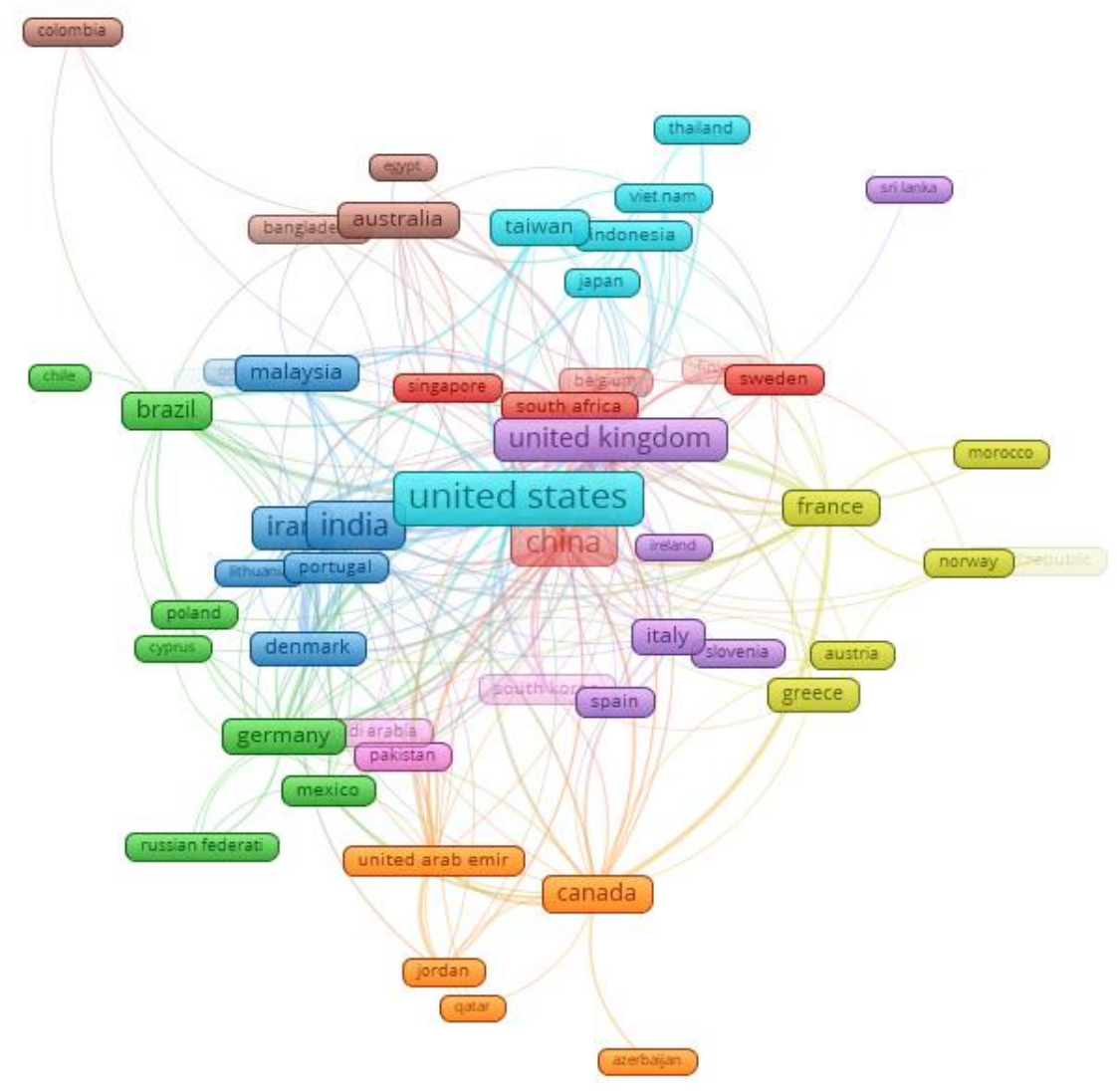

Figure 3. A screenshot of the bibliometric map created based on co-authorships with network visualisation mode

\section{Co-occurrence (Author Keywords)}

Figure 5 shows that "RL" was the most common keyword, occurring 1146 times, with 397 links to other keywords, frequently followed by remanufacturing. Suggestions for remanufacturing will be research hot spot in 2020. Remanufacturing, an essential part of RL, is the process that transforms waste products into a "new" state again (Xia et al., 2011). Furthermore, recalling customers' used products for remanufacturing can enhance the value of returned products and decrease the total cost (Sharma et al., 2011). Thus, remanufacturing is crucial for the organisation to recapture value (Banihashemi et al., 2019). Conversely, sustainable development is a research focus among the ten most prolific authors in the RL research area. However, no streams of keywords occurrence were identified in the review, which linked RL and sustainability development. 


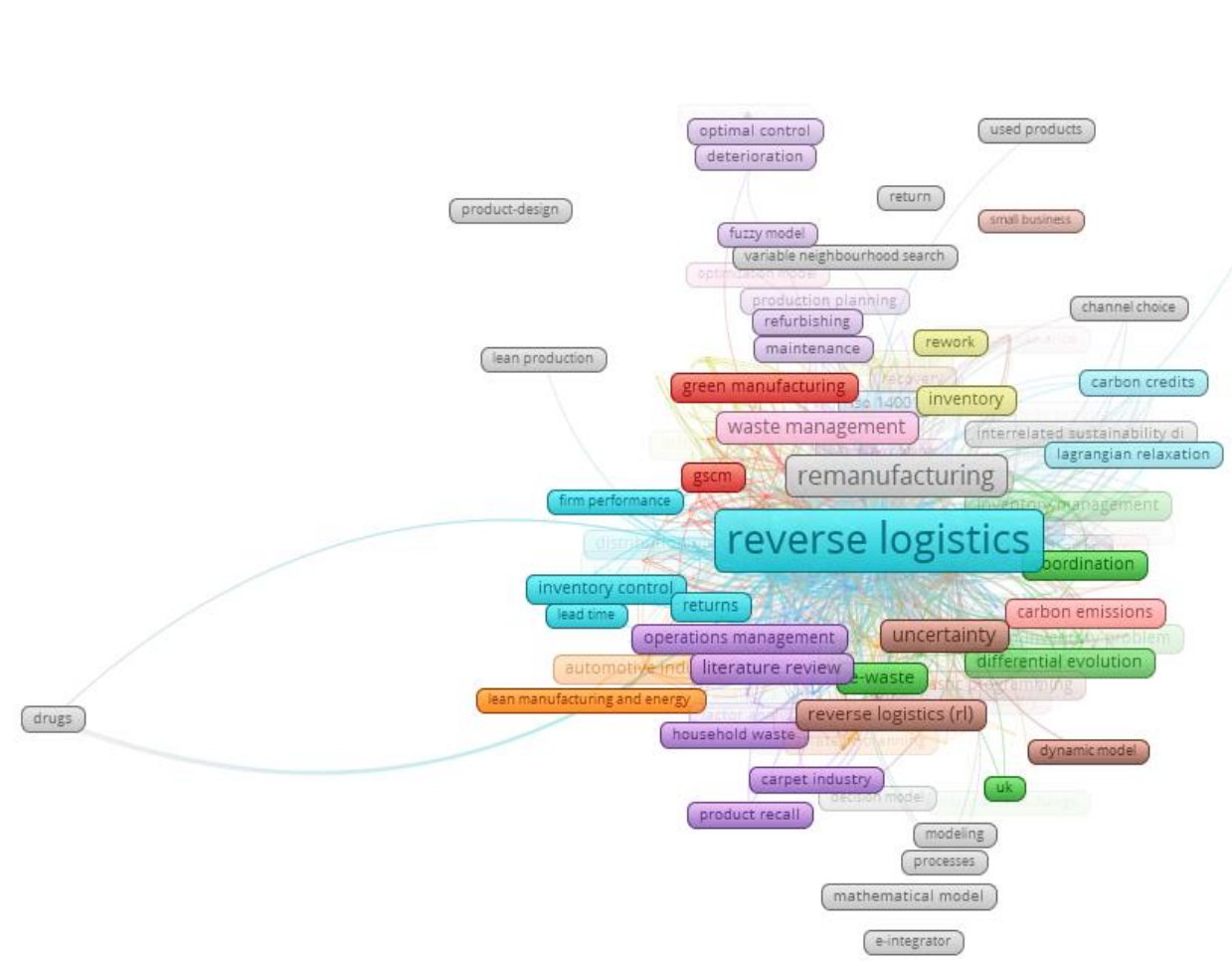

Figure 4. Screenshots of bibliometric maps created based on the author's keyword cooccurrence and overlay visualisation mode

[Note: The minimum number of keyword occurrences was set to 5]

\section{Limitations}

The current study is subjected to several limitations. Firstly, the analysis is limited to the Scopus database only. Thus, further analysis can be performed using other databases, such as Web of Science, Google Scholar or MedLine, and combinations of these databases. Additionally, only co-authorship and co-occurrence analyses were performed by utilising the VOSviewer. Hence, additional tools, such as co-citation and bibliographic coupling of the software, can be performed by utilising the same software. As RL is significant worldwide, the $\mathrm{RL}$ studies boundaries are anticipated to expand continuously, and further exciting issues and propositions will be identified.

\section{Conclusion}

Conclusively, the bibliometric analysis outlines RL research trends according to 1146 publications retrieved from the Scopus database. Publications have proliferated in the last decade and are expected to increase gradually. However, the lack of specialised theoretical development and journals in this field should be noted. In addition, the study identified countries and academic institutions with prominent publications and solid international collaboration (e.g., USA and United Kingdom). These institutions and countries are prospects for researchers from other nations to broaden their research collaborations. Similarly, the relationship of $\mathrm{RL}$ with the sustainability performance that provides future direction for academicians, practitioners and researchers in their research work on RL should be extensively studied. 
As RL-related research in developing countries started late, studies relevant to industryspecific studies are also limited. For example, China's RL development progress as a developing country is slow, which provides an opportunity for researchers. Finally, studies on remanufacturing is a principle $\mathrm{RL}$ topic, with a well-established body of knowledge. Nevertheless, as remanufacturing is only an element of $\mathrm{RL}$, the non-proportional focus on remanufacturing currently proposes that numerous remaining key $\mathrm{RL}$ areas remain unexplored and requires further research.

\section{References}

Agrawal, S., Singh, R. K., \& Murtaza, Q. (2016). Disposition decisions in reverse logistics by using AHP-fuzzy TOPSIS approach. Journal of Modelling in Management, 11(4), 932948.

Aitken, J., \& Harrison, A. (2013). Supply governance structures for reverse logistics systems. International Journal of Operations \& Production Management, 33 (6), 745-764.

Alkahtani, M., Ziout, A., Salah, B., Alatefi, M., Abd Elgawad, A. E. E., Badwelan, A., \& Syarif, U. (2021). An Insight into Reverse logistics with a Focus on Collection Systems. Sustainability, 13(2), 548.

Bai, C., \& Sarkis, J. (2013). Flexibility in Reverse logistics: a framework and evaluation approach. Journal of Cleaner Production, 47(1), 306-318.

Banihashemi, T.A., Fei, J. \& Chen, P.S.-L. (2019). Exploring the relationship between reverse logistics and sustainability performance: A literature review. Modern Supply Chain Research and Applications, 1(1), 2-27.

Bensalem, A., \& Kin, V. (2019). A bibliometric analysis of reverse logistics from 1992 to 2017. Supply Chain Forum: An International Journal, 20(1),15-28.

Blackburn, J. D., Guide, V. D. R., Souza, G. C., \& Van Wassenhove, L. N. (2004). Reverse supply chains for commercial returns. California Management Review, 46(2), 6-22.

Campos, H. K. T. (2014). Recycling in Brazil: challenges and prospects. Resources, Conservation and Recycling, 85, 130-8.

Carter, C. R., \& Ellram, L. M. (1998). Reverse logistics: a review of the literature and framework for future investigation. Journal of Business Logistics, 19 (1), 85-102.

Charvet, F. F., Cooper, M. C., \& Gardner, J. T. (2008). The structure of intelligence of Supply Chain Management: A Bibliometric Approach. Journal of Business Logistics, 29 (1), 4773.

Culnan, M. J. (1987). Mapping the structure of intelligence of MIS, 1980-1985: A Co-Citation Analysis. Management of Information System Quarte Reverse logistics, 11 (3), 341-353.

Evren, S., \& Kozak, N. (2014). Bibliometric analysis of tourism and hospitality related articles published in Turkey. Anatolia, 25(1), 61-80.

Falagas, M. E., Pitsouni, E. I., Malietzis, G. A., \& Pappas, G. (2008). Comparison of PubMed, Scopus, Web of Science, and Google Scholar: strengths and weaknesses. The FASEB Journal, 22(2), 338-342.

Franceschini, F., Maisano, D., \& Mastrogiacomo, L. (2016). Empirical analysis and classification of database errors in Scopus and Web of Science. Journal of Informetrics, 10(4), 933953.

Giannakis, M. (2012). The structure of intelligence of the Supply Chain Management Discipline: A Citation and Social Network Analysis. Journal of Enterprise Information Management, 25 (2): 136-169.

Govindan, K., Soleimani, H., and Kannan, D. (2015). Reverse Logistics and Closed-Loop Supply 
Chain: A Comprehensive Review to Explore the Future. European Journal of Operational Research, 240 (3): 603-626.

Gundolf, K. M., \& Filser, M. (2013). Management Research and Religion: A Citation Analysis. Journal of Business Ethics, 112 (1), 177-185.

Ho, G. T. S., Lam, C. H. Y., \& Wong, D. W. (2012). Factors influencing implementation of REVERSE LOGISTICS: a survey among Hong Kong businesses. Measuring Business Excellence, 16 (3), 26-46.

Jayaraman, V., \& Luo, Y. (2007). Creating competitive advantages through new value creation: a reverse logistics perspective. Academy of Management Perspectives, 21(2), 56-73.

Kopicki, R., Berg, M. J., Legg, L., Dasappa, V., \& Maggioni, C. (1993). Reuse and Recycling Reverse logistics Opportunities. Council of Logistics Management: Oak Brook, IL.

Lambert, D. M., \& Stock, J. R. (1982), Strategic Physical Distribution Management. Irwin, Homewood, IL.

Li, X., Ma, E., \& Qu, H. (2017). Knowledge mapping of hospitality research - A visual analysis using CiteSpace. International Journal of Hospitality Management, 60, 77-93.

Lopes, D. M. M., D’Agosto, M. A., Ferreira, A. F., \& Oliveira, C. M. de. (2014). Improving postsale reverse logistics in department stores: A Brazilian case study. Journal of Transport Literature, 8 (2), 325-48.

Mishra, R., \& Napier, R. (2014). Reverse logistics: antecedents of successful implementation and firm performance effects. Journal of Supply Chain and Operations Management, 12(2), 33-49.

Muñoz-Leiva, F., Porcu, L., \& Barrio-García, S. del. (2015). Discovering prominent themes in integrated marketing communication research from 1991 to 2012: a co-word analytic approach. International Journal of Advertising, 34(4), 678-701.

Murphy, P. (1986). A preliminary study of transportation and warehousing aspects of reverse distribution. Transportation Journal, 25(4), 12-21.

Murphy, P., \& Poist, R. (1989). Management of logistical retro movements: an empirical analysis of literature suggestions. Journal of the Transportation Research Forum, 29(1), 177-184.

Pourmohammadi, H., Dessouky, M., \& Rahimi, M. (2008). Sustainable reverse logistics for distribution of industrial waste/by products: A joint optimization of operation and environmental costs. Supply Chain Forum: An International Journal. 9(1). 2-17.

Raghuram, S., Tuertscher, P., \& Garud, R. (2010). Mapping the field of virtual work: a cocitation analysis. Information Systems Research, 21 (4), 983-999.

Ramos, T. R. P., Gomes, M. I., \& Barbosa-Póvoa, A. P. (2014). Planning a sustainable reverse logistics system: Balancing costs with environmental and social concerns. Omega, 48, 60-74.

Ravi, V., \& Shankar, R. (2012). Evaluating alternatives in reverse logistics for automobile organisations. International Journal of Logistics System and Management, 12(1), 32-51.

Rogers, D. S., Melamed, B., \& Lembke, R. S. (2012). Modeling and Analysis of Reverse Logistics. Journal of Business Logistics, 33(2), 107-117.

Sharma, S. K., Panda, B. N., Mahapatra, S. S., \& Sahu, S. (2011). Analysis of Barriers for Reverse Logistics: An Indian Perspective. International Journal of Modeling and Optimization, 101-106.

Stock, J. R. (1992), Reverse logistics. Council of Logistics Management: Oak Brook, IL.

Stock, J. R. (1998). Development and Implementation of REVERSE LOGISTICS Programs. Council of Logistics Management: Oak Brook, IL. 
Tibben-Lembke, R. S., \& Rogers, D. S. (2002). Differences between forward and reverse logistics in a retail environment. Supply Chain Management: An International Journal, 7 (5), 271-282.

Wang, J.-J., Chen, H., Rogers, D. S., Ellram, L. M., \& Grawe, S. J. (2017). A bibliometric analysis of reverse logistics research (1992-2015) and opportunities for future research. International Journal of Physical Distribution \& Logistics Management, 47(8), 666-687.

Wen-hui, X., Dian-yan, J., \& Yu-ying, H. (2011). The remanufacturing reverse logistics management based on Closed-loop supply chain management processes. Procedia Environmental Sciences, 11, 351-354. 